\title{
Does Auditor Tenure Reduce Audit Quality?
}

\author{
Junaidi \\ Universitas Teknologi Yogyakarta, Indonesia \\ Setiyono Miharjo \\ Universitas Gadjah Mada, Yogyakarta, Indonesia \\ Bambang Hartadi \\ Universitas Teknologi Yogyakarta, Indonesia
}

\begin{abstract}
Reduced auditor independence and the rise of corporate accounting manipulations have caused trust of the users in audited financial statements to begin to decline, so users of financial statements are questioning whether public accountants are independent parties. This research issue is related to the Decree of the Minister of Finance No. 17 in 2008 about public accountant services. Giving attestation services, in the form of financial statements about an entity, are conducted by the audit firm for no longer than 6 consecutive fiscal years and by a public accountant for 3 consecutive fiscal years at the longest. The purpose of this research is to examine empirically the influence of auditor tenure on audit quality. Auditor tenure is measured as the length of the auditor-client relationship. Audit quality is measured by the propensity of auditors to issue a going-concern opinion. This study uses a sample of firms listed on the Indonesia Stock Exchange during the 2003-2008 period. Research analysis uses logit model to measure the effect of auditor tenure on the auditors' propensity to publish a going-concern opinion. The hypothesis which states that the length of auditor tenure influences negatively the propensity of auditors to issue a going-concern opinion is statistically supported. This research is expected to provide empirical evidence about the importance of limiting of the auditor-client relationship.
\end{abstract}

\begin{abstract}
Abstrak: Berkurangnya independensi auditor dan maraknya manipulasi akuntansi korporat membuat kepercayaan para pemakai laporan keuangan auditan mulai menurun, sehingga para pemakai laporan keuangan mempertanyakan eksistensi akuntan publik sebagai pihak independen. Isu penelitian ini berkaitan dengan peraturan Menteri Keuangan No. 17 tahun 2008 tentang jasa akuntan publik. Pemberian jasa atestasi atas laporan keuangan dari suatu entitas yang dilakukan oleh Kantor Akuntan Publik paling lama untuk 6 (enam) tahun buku berturut-turut dan oleh seorang Akuntan Publik paling lama untuk 3 (tiga) tahun buku berturut-turut.Tujuan penelitian ini adalah untuk menguji secara empiris pengaruh tenur auditor terhadap kualitas audit. Tenur auditor diukur dengan lamanya hubungan auditor dengan klien. Kualitas audit diukur dengan kecenderungan auditor mengeluarkan opini going concern. Penelitian ini menggunakan sampel perusahaan yang terdaftar di Bursa Efek Indonesia perioda 2003-2008. Analisis penelitian
\end{abstract}


menggunakan model logit untuk mengukur pengaruh tenur auditor pada kecenderungan auditor mengeluarkan opini going concern. Hipotesis yang menyatakan bahwa terdapat pengaruh negatif tenur auditor pada kecenderungan auditor mengeluarkan opini going concern secara statistik didukung. Penelitian ini diharapkan dapat memberikan bukti empiris tentang pentingnya pembatasan hubungan auditor dengan klien.

Keywords: audit quality; auditor tenure; going concern; reputation 


\section{Introduction}

This paper aims to test empirically whether auditor tenure can reduce audit quality. This research issue relates to the Decree of the Minister of Finance No. 17 of 2008 on public accountant services. Attestation services producing financial statements for an entity are conducted by the audit firm for a maximum of 6 consecutive fiscal years and by a public accountant for a maximum of three consecutive fiscal years. The auditor tenure is measured by the length of the relationship between the auditor and the client (Mansi 2004). One of the audit quality indicators is the tendency of auditors to issue a going concern opinion (Geiger and Raghunandan 2000; Carey and Simnett 2006; Knechel and Vanstraelen 2007). They assume that the decline in audit quality is indicated by the auditor not issuing a going-concern opinion for firms experiencing financial difficulties.

The Indonesian Institute of Accountants has adopted the auditing standards that relate to the going-concern assumption established in the United States in SAS no. 59. In 1988 the Auditing Standards Board (ASB) issued Statement on Auditing Standard (SAS) No. 59: 'The auditor's consideration of an entity's ability to continue as a going-concern which askes the auditor to evaluate whether there is substantial doubt about the ability of the company client to continue as a going-concern or not." The Indonesian Institute of Accountants adopted SAS No. 59 to Statement of Auditing Standards No. 30 regarding the consideration of entities ability to survive in the auditor's opinion. Statement of Auditing Standards No. 30 requires the auditor's report to give warning to the users of financial statements. There is skepticism about the ability of the company, as an entity, to survive for at least one accounting period after the date of the financial statements or, collectively, the appropriate time period.

Reduced auditor independence and the rise of corporate accounting manipulations have begun to cause the trust of users of audited financial statements to decline, and they may question whether public accountants are independent parties. The Enron case demonstrated the desire of directors to obtain incentives such as bonuses encouraged them to manipulate the financial statements that resulted in bankruptcy of the company. The fraud committed by Enron involved the international accounting firm Arthur Anderson (AA) too. Arthur Anderson is one of the Big Five public audit firms. It intentionally or unintentionally had been trying to cover the financial problems faced by Enron. It caused huge losses for investors in the U.S. and around the world.

The results of studies that examine the effect of tenure and partner tenure on audit quality show inconclusive results. The results indicate a rejection of the statement about the negative effect of auditor tenure and partner tenure on audit quality (Ghosh and Moon 2005; Myers et al. 2003; Geiger and Raghunandan 2002; Manry et al. 2003). Other research findings indicate that audit quality decreases with the increasing duration of the auditor tenure (Davis et al. 2002 in Ghosh and Moon 2005). Knechel and Vanstraelen (2007) showed that the decision of auditor to issue a going-concern opinion was not influenced by the auditor tenure in a sample of bankrupt companies. In this sample, they found some evidence of a negative relationship between tenure and auditor's going-concern opinion. They further state that the evidence of whether auditor tenure either improves or degrades the quality is weak. Carey and Simnett (2006) showed that 
there were significant negative relationships between partner tenure and audit quality.

The inclusion of the explanation about the company's condition in the notes of financial statements and audit opinions is considered largely in public accountancy as a 'warning' to the readers of financial statements about the company's financial condition (Purba 2009: 78). When the economic climate is one of uncertainty, investors expect auditors to provide an 'early warning' for the possibility of a company's financial failure (Praptitorini and Januarti 2005). The investors will rely heavily on information issued by the auditor for making investment decisions. Users of financial statements should be alert for the possible failure of a company, due to operational and financial problems, as well as external companies.

However, in most management companies, the inclusion of an explanation about the company's condition, either in the notes of financial statements or as an auditor's opinion, is feared because it can create a bad image for the company. The public accountant could worsen the situation by causing pessimism on the part of financial statement readers. The company could actually go bankrupt because of the creation of such a bad image by the external auditors. It could become a 'self-fulfilling prophecy' created by the the auditors.

Furthermore there are numerous studies that reveal the factors associated with going-concern opinions, they are Mutchler (1984; 1986); Menon and Schwartz (1987); Dopuch et al. (1987); Koh (1991); Koh and Tan (1999); Geiger and Raghunandan (2002); Ghosh and Moon (2004); Geiger and Rama (2006); Kirkos et al. (2007) and Haron et al. (2009). Research in Indonesia related to going-concern opinions has been performed by
Fanny and Saputra (2000); Mayangsari (2003); Komalasari (2004); Santosa and Wedari (2007); Januarti and Fitriani (2008). These studies use different variables that are both financial and non-financial.

Audit quality is measured by the propensity of the auditor to issue a going-concern opinion. The results of this study indicate that the decision by an auditor to issue one is influenced by the auditor's tenure. The results of this study are expected to contribute to and support the regulation of the quality of auditing by the regulator with regard to auditor rotation. The composition of the study: in the next section we provide a review of theory and literature about auditor tenure and audit quality; the third section discusses the research method; the fourth section discusses the analysis; and the last section presents conclusions and suggestions.

\section{Theory and Hypothesis}

\section{Regulation of Going-Concern}

Bellovary et al. (1976) explain that before 1962 there had been no formal guidance on the assessment of the going-concern status of a company in America. Then in 1962, the Stock Exchange Commission (SEC) was the first to address issues of going-concern when it issued Accounting Series Release (ASR) No. 90. In 1974, the AICPA issued SAS No. 2, which provided the first specific discussion about items that are important to consider when assessing the company's going-concern status. After issuing SAS No. 34 in 1981, the AICPA then issued SAS No. 59 in 1988, that further discussed this topic. There were three main changes from SAS No. 34 to SAS No. 59, namely stipulating the following requirements that: (1) the auditor will 
consider the going-concern status of clients for each audit engagement, (2) the audit report will be modified if there is substantial doubt about the going-concern status of companies, and (3) audit report will include an explanatory paragraph regarding any substantial doubt.

In 1988 the Auditing Standards Board (ASB) issued Statement on Auditing Standard (SAS) No. 59: 'The auditor's consideration of an entity's ability to continue as a goingconcern' that asks the auditor to evaluate any substantial doubt about the ability of the client company to continue as a going-concern. SAS No. 59 asks the auditor to accumulate and evaluate evidence to determine whether the going-concern status is questionable or not. The auditors consider the issuance of a going-concern opinion if they find a reason for doubting the sustainability of an enterprise based on testing.

The Indonesian Institute of Accountants adopted a 59 about the auditor's consideration of the entities' ability to continue to survive. 59 required the auditor to give warning to the users of financial statements. This is where there is skepticism about the ability of company, as an entity, to survive for at least in one accounting period after the date of the financial statements, or collectively, the appropriate time period. 59, paragraph 2, states that the auditor is responsible for evaluating any major doubts about the continued survival of entities the within a reasonable period of time, not more than one year from the date of the financial statements being audited (the next period will be referred to the appropriate period). Evaluation of the auditor is based on knowledge of existing conditions and events that have occurred during or before completing field work. Information about conditions and events is obtained from the application of audit procedures. They are planned and implemented to achieve the objectives of the audit. It is concerned with the assertions of management contained in the financial statements being audited, as described in section Auditing Standards 326.

Statement of Auditing Standards No.30 requires the auditor to give warning to the users of financial statements, that there is a doubt about the ability of the company as an entity, to survive, at least in one accounting period after the date of this report or referred to the appropriate period. Statement of Auditing Standards 30 paragraph 2 requires that the auditor is responsible for evaluating any major doubts on the entities ability in the continued survival within a reasonable period, not exceeding one year from the date of the financial statements being audited.

\section{Tenure and Audit Quality}

Decree of Ministry of Finance No. 17 of 2008, the second part, describes the restrictions on the provision of auditor services. In this case the provision of general audit services about the financial statements of an entity is referred to in paragraph (1) letter a. It is carried out by an audit firm for 6 consecutive fiscal years at most and by a public accountant for a maximum of three consecutive fiscal years. Auditor tenure shows long auditor-client relationships (Mansi 2004). Auditor tenure can have a negative impact on auditor independence. Long auditor tenure can improve the competence of auditors as they can base their decisions on the extensive knowledge that they have developed over time, or it can damage the indepedence of the auditors because the long-standing relationship fosters closeness between management and auditors. Short auditor tenure can 
undermine the competence of auditor because the auditor may have a lack of knowledge about the company in the early years of auditing. It also could damage the independence of auditors, as auditors will want to retain new clients long enough to cover the cost of setting the initial audit or lowball fee (Dye 1991).

There are two main arguments supporting a negative association between the duration of auditors tenure and audit quality: (1) the threat to the independence that may result from growing personal relationship between the auditor and the client, and (2) reduction in audit partner capacity to give a critical appraisal (Carey and Simnett 2006). The development of personal relationships between client management and audit partner would threaten auditor independence. Mauts and Sharaf (1961: 231) state that the auditor should be aware of the various pressures that tend to influence their attitudes and thus slowly but surely threaten their independence. The threat to independence is not only happening at the time of reporting, but it also has the potential to impact assessment carried out during the audit (Dopuch et al. 2003; Bazerman et al. 1997). Thus, this suggests that a long personal relationship would impact auditor independence and objectivity. Specific arguments are that the consequences of decreasing independence with the length of partner tenure of an auditor, include the possibility of surrendering to the inevitable pressure of clients in audit conflict situations and, in the extreme, the possibility that the excessive familiarity would result in collusion between client and auditor (McLaren 1958).

Proponents of auditor rotation argue that the rotation will provide a 'fresh look' at the company's financial information (Davis et al. 2000). They claim that the longer an audit firm maintains a client, the less that audit firm is able to maintain its objectivity when examining a client statement, and the more likely there will be no mistakes that are detected in the financial statements.

Lack of objectivity has a variety of sources. First, it is said that from time to time it is identified when auditors begin to act as advocates for management. As a consequence, rather than see the assertions of management with appropriate professional skepticism, auditors will look at it from the perspective of support for the management. Second, auditors become unsuccessful at seeing and inserting new evidence or a change in the client's situation into their assessment. This behavior may lead to the auditor's failure in revising assessments about the compliance during the previous year, despite the assertions of facts and circumstances that have changed (for example, failure to give proper weight to new evidence regarding the possibility of loss contingencies). Lastly, it is said that the ability to retain clients without any time limit provides an incentive for auditors to defer to the client in the case of a dispute, and if the auditors do otherwise it would result in the loss of the client. This argument is supported by studies showing the startup costs that are incurred by the auditor during the first year of involvement, and that the auditor can obtain economic rents for the next year's audit as long as they retain the client (DeAngelo 1981; Davis et al. 1993; O 'Keefe, et al. 1994).

Longer auditor tenure may be associated with reduced alertness through overfamiliarity with the client (Mautz and Sharaf 1961). The long duration of auditor tenure may create economic incentives for auditors to be less independent. In this case, the auditor can accept clients' demands in order to continue to secure audit fees in the future (Hoyle 1978). Davis et al. (2002) con- 
clude that audit quality decreases as the length of tenure increases (Ghosh and Moon 2005). Knechel and Vanstraelen (2007) show that the auditor's decision to issue a goingconcern opinion is not influenced by tenure. In their sample of bankrupt companies, they did not find any evidence of a negative relationship between auditor tenure and publishing a going-concern opinion. They further state that the evidence of tenure either improving or degrading the quality is weak. Carey and Simnett (2006) show there are significant negative relationships between audit partner tenure and the quality of audits. Based on theories and research that have been explained above, the hypothesis can be formulated as follows:

Hypothesis: auditor tenure negatively influences the propensity of auditors to issue a goingconcern opinion.

\section{Research Methods}

\section{Data}

This study uses data from companies listed on the Indonesia Stock Exchange between 2003 and 2008, that consistently present information on the financial statements and the reports of independent auditors.

\section{Research Model}

$$
\begin{aligned}
\mathrm{GC}= & \mathrm{a}+\mathrm{b}_{1} \text { Tenure }+\mathrm{b}_{2} \text { Reputation } \\
& +\mathrm{b}_{3} \text { Size }+\mathrm{e}
\end{aligned}
$$

\section{Operational Definition}

\section{Dependent Variable}

Dependent variable is a dummy variable related to the opinion given by the auditor. An auditor who concludes that there is substantial doubt regarding the suitability of the assumption of going-concern will give goingconcern opinion. While the clean opinion is the auditor's opinion given to the company's financial statements presented fairly in accordance with generally acceptable accounting standards. Clean opinion is also called an unqualified opinion. Dependent variable gives the value 1 if the auditor's going-concern opinion is given.

\section{Independent Variable}

The independent variable used in this study is tenure. To measure this variable, the researchers used data about how long the audit firm has had a relationship with the clients, measured in years. Based on the Decree of Minister of Finance No: 17/PMK.01/ 2008 of public accountant services, and the Chairman of Bapepam Regulation No. Kep310/BL/2008 of service governing public accountant regard that the provision of general audit services of the financial statements of an entity by an audit firm should last for a maximum of six consecutive fiscal years while by a certified public accountant it is a maximum of three consecutive fiscal years.

\section{Control Variable}

This study used two control variables, namely the auditor's reputation and company size. Auditor reputation is measured by us- 
ing a categorical variable. Researchers provide a value of 1 if the audit firm is included in the Big 4. And they profit value of 0 if it is not included in the non Big 4. Mutchler, Hopwood, and McKeown (1997) found evidence of univariate where Big 6 auditors tend to issue going-concern audit opinions on the companies that experience financial distress more than non-Big 6 auditor. Large audit firms can provide better quality audits than small firms, including the express going-concern problem. DeFond, Raghunandan, and Subramanyam (2002) show evidence that the Big 4 audit firms are more likely to report going-concern audit report problems than non-Big 4 firms. Company size is a control variable, as it is measured using the natural log of total assets of the company. Previous research indicates that the auditor issues a going-concern opinion that is inversely proportional to the size of the client company (Mutchler et al., 1997; Knechel and Vanstraelen 2007).

\section{Analysis}

\section{Data Description}

Based on the criteria of the sample obtained in the following data (Table 1).
Based on the opinion issued by the auditors on 89 samples of the company see are Table 2.

\section{Descriptive Statistics}

Based on the descriptive analysis (Table 3 ), it shows that tenure range is from 1 to 11 years, and the average is 3.1667. This indicates that the samples obtained from the engagement between the auditor and the client. There is a commitment that goes beyond the limits set by the government. The period of the engagement between the auditors and client are on average more than 50 percent of the allowable period of engagement

Table 1. Sample Data

\section{Description}

Total

Companies that publish

financial statements

from the year 2003 - 2008

consistently

Data incomplete

Sample

Table 2. The Auditor's Opinion Data

\begin{tabular}{lccccccc}
\hline Opinion & \multicolumn{6}{c}{ Year } & \\
\cline { 2 - 7 } & $\mathbf{2 0 0 3}$ & $\mathbf{2 0 0 4}$ & $\mathbf{2 0 0 5}$ & $\mathbf{2 0 0 6}$ & $\mathbf{2 0 0 7}$ & $\mathbf{2 0 0 8}$ & Total \\
\cline { 2 - 7 } Going concern & 72 & 70 & 61 & 46 & 49 & 49 & 347 \\
Clean opinion & 17 & 19 & 28 & 43 & 40 & 40 & 187 \\
Total & 89 & 89 & 89 & 89 & 89 & 89 & 534 \\
\hline
\end{tabular}


Table 3. Descriptive Statistics

\begin{tabular}{lrrrrr}
\hline & N & Minimum & Maximum & Mean & Std. Deviation \\
\cline { 2 - 6 } OPINION & 534 & .00 & 1.00 & .6517 & .47688 \\
TENURE & 534 & 1.00 & 11.00 & 3.1667 & 1.98785 \\
REPUTATION & 534 & .00 & 1.00 & .4869 & .50030 \\
ASSET & 534 & 8.00 & 15.00 & 11.6180 & 1.05395 \\
Valid N (listwise) & 534 & & & & \\
\hline
\end{tabular}

\section{Test Feasibility of Regression Models}

Based on the omnibus test of model coefficients, it indicates any significant models. The model presented is expected to explain variations in the independent variable and the dependent variable. Nagelkerke $R$ Square value indicates the value of 0.037 , which means that the variation of the independent variables could explain the 3.7 percent of the dependent variable, while the rest is influenced by other variables that's not included in the research model (Table 4). Although the value of Nagelkerke $R$ Square is relatively small, there does not mean a model misspecification. The standard error values of the constants are quite large, which means that many possible variables have not been included in the model. This is certainly an opportunity for subsequent research. The level of model predictions are 98 percent for going-concern, and 7 percent for the clean opinion. Overall the variables tenure, reputation, and firm size can explain the going concern opinion by 66.3 percent (Table 5 ).

\section{Testing of Hypothesis}

The results of the analysis of auditor tenure influence the issuing opinions of going propensity can be seen in Table 6 .

According to the analysis of tenure variable, the value of the coefficient of -0.124 with a significance level of 0.009 is indicateds. The negative cooficient suggests that the longer the auditor's tenure, the lower the tendency for the auditors to issue a going-concern opinion. Further figures show a significance value less than 0.009 alpha 0.05 . Therefore, it statistically supports hypothesis presented. The results support previous research findings conducted by Davis et al. (2002), Carey and Simnett (2006) and Knechel and Vanstraelen (2007). 
Table 4. Omnibus Test of Model Coefficient

\begin{tabular}{|c|c|c|c|c|c|}
\hline \multirow[b]{2}{*}{ Step } & \multicolumn{5}{|c|}{ Model Summary } \\
\hline & -2 Log likelihood & \multicolumn{3}{|c|}{ Cox and Snell $\mathbf{R}$ Square } & Nagelkerke R Square \\
\hline 1 & $675.997^{\mathrm{a}}$ & \multicolumn{3}{|c|}{.027} & .037 \\
\hline \multicolumn{6}{|c|}{ a. Estimation terminated at iteration number 4 because parameter estimates changed by less than 0.001 . } \\
\hline \multicolumn{6}{|c|}{$\begin{array}{l}\text { Table 5. The ability of the model in explaining the going-concern opinion Classification } \\
\text { Table }^{\mathrm{a}}\end{array}$} \\
\hline \multicolumn{6}{|c|}{ Classification Tablea } \\
\hline & & & \multicolumn{3}{|c|}{ Predicted } \\
\hline & & & \multicolumn{2}{|c|}{ OPINION } & \\
\hline & Observed & & Clean & $\overline{g c}$ & Percentage Correct \\
\hline \multirow[t]{3}{*}{ Step 1} & OPINION & clean & 13 & 173 & 7.0 \\
\hline & & $\mathrm{gc}$ & 7 & 341 & 98.0 \\
\hline & Overall Percentage & & & 66.3 & \\
\hline
\end{tabular}

a. The cut value is 0.500

Table 6. Statistical Testing

Variables in the Equation

\begin{tabular}{|c|c|c|c|c|c|c|c|}
\hline \multirow{5}{*}{ Step $1^{a}$} & & B & S.E. & Wald & df & Sig. & $\operatorname{Exp}(B)$ \\
\hline & TENURE & -0.124 & 0.048 & 6.803 & 1 & 0.009 & 0.883 \\
\hline & REPUTATION & 0.537 & 0.213 & 6.362 & 1 & 0.012 & 1.710 \\
\hline & ASSET & 0.078 & 0.099 & 0.611 & 1 & 0.434 & 1.081 \\
\hline & Constant & -0.127 & 1.114 & 0.013 & 1 & 0.909 & 0.881 \\
\hline
\end{tabular}

a. Variable(s) entered on step 1: TENURE, REPUTATION, ASSET. 
Therefore it is a conflict of interest that can not be avoided. The auditor will lose its independence and accommodate clients' interests, with the hope of the engagement with the clients will not be disconnected. If the assignment of auditors are now preserved for a long time in the future, then most likely, the auditor will feel comfortable. Therefore the objectivity of the audit will be undermined (Mautz and Sharaf 1961). Auditor reputation variables as control variables show a significant value. These findings support the research of Lennox (1999), Geiger and Rama (2006). While the size variable does not significantly affect the issuance of going-concern opinions. These findings support the research of Chen et al. (2001), but are in contrast to the results of research are Wedari and Santosa (2007).

\section{Conclusion and Suggestion}

According to the results of the research, setting limitations on the auditor's relation- ship with the client is still being debated. Setting the auditor's relationship with clients is important because relationships with auditors arranged by the management can reduce the independence of auditors. This study examines empirically the impact of auditor tenure on audit quality. According to the statistical analysis, the length of relationship between auditors and clients has a significantly negative effect on the propensity to issue goingconcern opinions. Therefore the hypothesis that was previously stated is supported by the statistics. The research still has limitations in terms of both of the variables tested and the study sample. Subsequent research can be expanded by looking at other indicators of audit quality, auditor rotation properties and expanding the sample data. Further research can also be extended to examine several variables that may affect auditor tenure.

\section{References}

BAPEPAM-LK. 2008. Keputusan Nomor: KEP-310/BL/2008: Independensi Akuntan yang Memberikan Jasa di Pasar Modal. www.bapepam.go.id.

Bazerman, M. H., K. P. Morgan, and G. F. Loewanstein. 1997. The Impossibility of auditor independence. Sloan Management Review 38 (Summer): 89-94.

Bellovary, J. L., D. E. Giacomino, and M. D. Akers. 2007. A review of going concern prediction studies: 1976 to present. Journal of Business \& Economics Research (2): 9-27.

Carcello, J. V., and A. L. Nagy. 2004. Audit firm tenure and faudulent financial reporting. Auditing: A Journal of Practice \& Theory 23 (2): 55-69.

Carey, P., and R. Simnett. 2006. Audit partner tenure and audit quality. The Accounting Review 81 (3): 653676.

Chen, C. J. P., and S. Chen, X. Su. 2001. Profitability regulation, earnings management and modified audit opinions: evidence from China. Auditing: A Journal of Practice and Theory 20: 9-30.

Davis, L. R., D. N. Ricchiute, and G. Trompeter. 1993. Audit Effort, Audit Fees, and the Provision of on Audit Services to Audit Clients. The Accounting Review 68 (January): 135-150. 
DeFond, M. L., K. Raghunandan, and K. R. Subramanyam. 2002. Do non-audit service fees impair auditor independence? Evidence from going concern opinion decisions. Journal of Accounting Research (June): 1247-1274.

Deangelo, L. E. 1981. Auditor independence, 'lowballing', and disclosure regulation. Journal of Accounting and Economics: 113-127.

Dopuch, N., R. King, and R. Schwartz. 2003. Independence in Appearance and in Fact: An Experimental Investigation. Contemporary Accounting Research 20: 79-115.

Dopuch, N., R. W. Holthausen, and R. W. Leftwich. 2004. Predicting audit qualification with financial and market variables. The Accounting Review LXIII (3): 117-128.

Dye, R. 1991. Informationnaly motivated auditor replacement. Journal of Accounting and Economics 14 (4): 347-374.

Fanny, M., and S. Saputra. 2005. Opini Audit Going Concern: Kajian Berdasarkan Model Prediksi Kebangkrutan, Pertumbuhan Perusahaan, dan Reputasi Kantor Akuntan Publik (Study pada Emiten Bursa Efek Jakarta). Prosiding SNA VIII, Solo.

Geiger, M. A., and K. Raghunandan. 2002. Auditor Tenure and Audit Reporting Failures. Auditing: A Journal of Practice \& Theory 21 (1): 67-78.

Geiger, M. A., and D. V. Rama. 2006. Audit firm size and going concern reporting accuracy. Accounting Horizons 20 (1): 1-17.

Ghosh, A., and D. Moon. 2004. Auditor tenure and perceptions of audit quality. Journal of Business Finance and Accounting 80 (2): 209-247.

Haron, H., B. Hartadi, M. Ansari, and I. Ismail. 2009. Factors influencing auditor's going concern opinion. Asian Academy of Management Journal 14 (1): 1-19.

Hoyle, J. 1978. Mandatory auditor rotation: The arguments and an alternative. Journal of Accountancy 145 (5): 69-78.

Ikatan Akuntan Indonesia. 2001. Standar Profesional Akuntan Publik, Jakarta: Salemba Empat.

Januarti, I., and E. Fitrianasari. 2008. Analisis rasio keuangan dan rasio non keuangan yang mempengaruhi auditor dalam memberikan opini going concern pada auditee: Studi empiris pada perusahaan manufaktur yang terdaftar di BEJ tahun 2000-2005. Jurnal Maksi UNDIP 8 (1): 43-58.

Jensen, M., and W. Mecking. 1976. Theory of the firm: Managerial behaviour, agency costs and ownership stucture. Journal of Financial Economics 3 (4): 305-360.

Knechel, W. R., and A. Vanstraelen. 2007. The relationship between auditor tenure and audit quality implied going concern opinions. Auditing: A Journal of Practice and Theory 26 (1): 113-131.

Komalasari, A. 2004. Analisis pengaruh kualitas opini auditor dan proxy going concern terhadap opini auditor. Jurnal Akuntansi dan Keuangan 9 (2): 1-14.

Koh, H. C., and S. S. Tan. 1999. A neural network approach to the prediction of going concern status. Accounting and Business Research 29 (3): 211-216.

Lennox, C. 1999. Are large auditors more accurate than small auditors? Accounting and Business Research 29 (3): 217-227.

Lim, C., and H. Tan. 2010. Does auditor tenure improve audit quality. Contemporaryy Accounting Research 27 (1): 923-957. 
Mansi, S., W. Maxwell. and D. Miller. 2004. Does auditor quality and tenure matter to investor? Journal of Accounting Research 23 (2): 17-30.

Manry, D. L., T. J. Mock, and J. L. Turner. 2008. Does increased audit partner tenure reduce audit quality? Journal of Accounting, Auditing \& Finance: 553-572.

Mautz, R. K., and H. A. Sharaf. 1961. The philosophy of auditing. American Accounting Association Monograph. Sarasota, Florida: American Accounting Assosiation.

Mayangsari, S. 2003. Pengaruh keahlian audit dan independensi terhadap pendapat audit: Sebuah kuasi eksperimen. Jurnal Riset Akuntansi Indonesia 6 (1): 1-22.

Menon, K., and K. B. Schwartz. 1987. An empirical investigation of audit qualification decision I presence of going concern uncertainties. Contemporary Accounting Research 3 (2): 302-315.

Mutchler, J. F. 1984. Auditors' perceptions of the going-concern opinion decision. A Journal of Practice \& Theory 3 (2): 17-30.

Mutchler, J. F. 1986. Empirical evidence regarding the auditor's going concern opinion decision. Auditing: A Journal of Practice and Theory 6 (1):148-163.

Mutchler, J. F., W. Hopwood, and J. M. McKeown. 1997. The influence of contrary information and mitigating factors on audit opinion decisions on bankrupt companies. Journal of Accounting Research 35 (2): 295-310.

Myers, J., I. Myers, and T. Omer. 2003. Exploring the term of auditor-client relationship and the quality of earnings: A case for mandatory auditor rotation? The Accounting Review 78 (3): 779-798.

O'Keefe, R., D. Simunic, and M. Stein. 1994. The production of audit services: Evidence from a major public accounting firm. Journal of Accounting Research 32 (2): 241-261.

Peraturan Menteri Keuangan. 2008. Peraturan Menteri Kenangan Nomor: 17/Pmk. 01/2008 Tentang Jasa Akuntan Publik. www.depkeu.go.id.

Purba, M. P. 2009. Asumsi Going Concern: Suatu Tinjauan Terhadap Dampak Krisis Kenangan. Graha Ilmu.

Santosa, A. F., and L. K. Wedari. 2007. Analisis faktor faktor yang mempengaruhi kecendeunagan penerimaan opini audit going concern. JAAI 11 (2): 141-158. 
